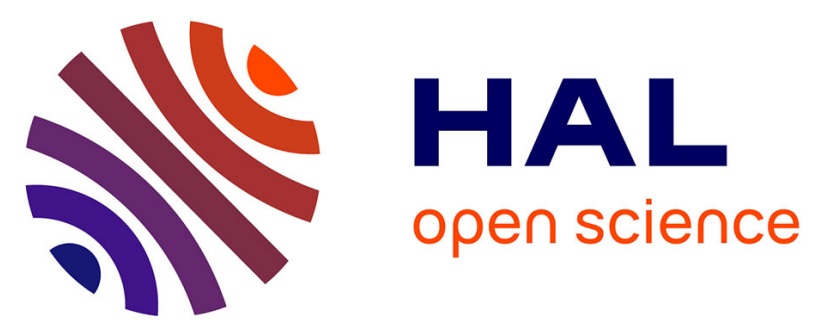

\title{
The majority of minerals present in natural rubber are associated with the macrogel: An ICP-MS and SEM/EDX investigation
}

Sebastien Rolere, Christine Char, Jean Marie Taulemesse, Anne Bergeret, Jerome St-Beuve, Frédéric Bonfils

\section{To cite this version:}

Sebastien Rolere, Christine Char, Jean Marie Taulemesse, Anne Bergeret, Jerome St-Beuve, et al.. The majority of minerals present in natural rubber are associated with the macrogel: An ICPMS and SEM/EDX investigation. Journal of Applied Polymer Science, 2016, 133 (9), pp.43062. 10.1002/app.43062 . hal-02906424

\section{HAL Id: hal-02906424 \\ https://hal.science/hal-02906424}

Submitted on 25 May 2021

HAL is a multi-disciplinary open access archive for the deposit and dissemination of scientific research documents, whether they are published or not. The documents may come from teaching and research institutions in France or abroad, or from public or private research centers.
L'archive ouverte pluridisciplinaire HAL, est destinée au dépôt et à la diffusion de documents scientifiques de niveau recherche, publiés ou non, émanant des établissements d'enseignement et de recherche français ou étrangers, des laboratoires publics ou privés. 


\title{
The majority of minerals present in natural rubber are associated with the macrogel: An ICP-MS and SEM/EDX investigation
}

\author{
Sébastien Rolere, ${ }^{1}$ Christine Char, ${ }^{1}$ Jean Marie Taulemesse, ${ }^{2}$ Anne Bergeret, ${ }^{2}$ \\ Jérôme Sainte-Beuve, ${ }^{1}$ Frédéric Bonfils ${ }^{1}$ \\ ${ }^{1}$ CIRAD, UMR IATE, Montpellier, F-34060, France \\ ${ }^{2}$ Ecole Des Mines D'alès, C2MA, Alès, F-30319, France \\ Correspondence to: F. Bonfils (E-mail: frederic.bonfils@cirad.fr)
}

\begin{abstract}
The mineral composition of the insoluble (macrogel) and soluble fractions of two natural rubber (NR) samples made from the latex of two different clones (RRIM600 from Thailand and GT1 from Côte d'Ivoire) was determined using inductively coupled plasma mass spectrometry (ICP-MS). The ICP-MS results showed that mineral elements were concentrated in the macrogel. The major mineral elements found in macrogel were phosphorus, magnesium, potassium, and sulfur. Some mineral elements were mostly concentrated in micron-sized mineral aggregates, visible at the surface of the samples using scanning electron microscopy coupled with an energy dispersive X-ray microanalyzer (SEM/EDX). The nature of these mineral aggregates was found to be highly variable. Their inhomogeneous distribution in the macrogel indicates that these aggregates do not have a major influence on macrogel structure.
\end{abstract}

KEYWORDS: characterization; gels; microscopy; properties; rubber

\section{INTRODUCTION}

Natural rubber (NR) is known to be composed of about $94 \%$ $\mathrm{w} / \mathrm{w}$ of cis-1,4-polyisoprene, and $6 \% \mathrm{w} / \mathrm{w}$ of non-isoprene (or "non-rubber") compounds, such as lipids (1.5\%-3\% w/w), proteins $(2 \% \mathrm{w} / \mathrm{w})$ and minerals $(0.2 \% \mathrm{w} / \mathrm{w}) .{ }^{1-3}$ Some of those non-isoprene compounds seem responsible for the superior mechanical properties of $\mathrm{NR}^{4-7}$ but also to influence its oxidation stability ${ }^{8}$ and its curing behavior. ${ }^{9}$ Some non-isoprene compounds are also assumed to interact somehow with the macromolecules of cis-1,4-polyisoprene, ${ }^{10}$ and to cause the existence of a gel phase in NR. ${ }^{11}$ This gel phase is composed of an insoluble fraction called "macrogel", and of microaggregates (microgel) dispersed in the soluble fraction. ${ }^{12-14}$ Several authors have studied the interactions that structure the gel phase of NR. Tanaka et al. ${ }^{10}$ suggested some physical interactions between phospholipids and proteins, and the $\alpha$ - and $\omega$ terminal groups of the polymer respectively, to explain macrogel structure. Other authors have studied the influence of metallic bivalent cations. Tarachiwin et al. ${ }^{15}$ showed that the macrogel was partly formed by ionic interactions caused by $\mathrm{Mg}^{2+}$ cations. Rippel et al. ${ }^{16}$ showed that the microaggregates making up the microgel of NR were highly concentrated in calcium. ${ }^{16}$ The authors suggested ionic interactions between $\mathrm{Ca}^{2+}$ cations and carbonyl groups, ${ }^{17}$ which are present on non- isoprene compounds mainly, ${ }^{18}$ but also on the macromolecules as abnormal groups. ${ }^{19-21}$

As Hevea brasiliensis latex is the cytoplasm of the laticiferous cells, it contains many minerals (Table I), which remain in NR samples. Minerals are present in the main latex fractions, including the rubber cream containing rubber particles. ${ }^{22}$ The main minerals identified in latex are potassium, sodium, magnesium and phosphorus. ${ }^{22,23}$ Their concentrations can vary depending on the clone and the season. ${ }^{24}$

The main objective of our studies was to compare the mineral composition of the soluble fraction and the macrogel of two NR samples made from latex of two different clones, using inductively coupled plasma mass spectrometry (ICP-MS). Mineral distributions in the cis-1,4-polyisoprene matrices were then studied by scanning electron microscopy coupled with an energy dispersive X-ray microanalyzer (SEM/EDX), in order to determine the role of minerals in the macrogel structure.

\section{EXPERIMENTAL}

\section{Materials}

Two NR samples of TSR10 grade (Technically specified rubber) were used. TSR grades account for more than $60 \%$ of global NR production. $^{30}$ Sample A1 was produced in Thailand (Thai Hua company) from the latex of clone RRIM600. Sample B1 was 
Table I. Mineral Composition of Hevea brasiliensis Latex, According to the Literature

\begin{tabular}{lll}
\hline & $\begin{array}{l}\text { Range of } \\
\text { concentrations } \\
\text { Mineral }\end{array}$ & \\
\hline $\mathrm{K}$ & $100-500$ & Reported in \\
\hline $\mathrm{Na}$ & $7-100$ & $23-26$ \\
$\mathrm{Mg}$ & $1-120$ & 25,26 \\
$\mathrm{Pi}$ & $10-70$ & $21-26$ \\
$\mathrm{Ca}$ & $0.05-30$ & $23,27,28$ \\
$\mathrm{Fe}$ & $1-12$ & $21-26$ \\
$\mathrm{Rb}$ & $0.7-4$ & 25,26 \\
$\mathrm{Cu}$ & $0.2-0.5$ & 26 \\
$\mathrm{Mn}$ & Traces & 23,26 \\
$\mathrm{Zn}$ & Traces & 26,29 \\
$\mathrm{~Pb}$ & Traces & 29 \\
\hline
\end{tabular}

Pi: inorganic phosphorus.

produced in Côte d'Ivoire (S.A.P.H. company) from the latex of clone GT1. These two clones are among the most frequently used. NR processing was controlled in local partner factories.

Each sample was homogenized according to standards ISO 1795 and ISO 2393, on a clean BLERE I.F. 50 \#1400 two-roll mill (51/64 model). The roll temperature was maintained at $27^{\circ} \mathrm{C}$ and the nip was $1.69 \mathrm{~mm}$. The speeds of the front and back rolls were 24 and $34 \mathrm{rpm}$, respectively.

\section{Separation of the NR Soluble Fraction and Macrogel}

Homogenized NR samples were dissolved at $0.5 \%(\mathrm{w} / \mathrm{v})$ in tetrahydrofuran (THF, HPLC grade) stabilized with $250 \mathrm{mg} / \mathrm{L}$ of 2,6-di-tert-butyl-4-methylphenol (BHT). The solutions were kept at $30^{\circ} \mathrm{C}$ in the dark. After 5 days, the soluble fraction and the macrogel were separated by centrifugation at $30,000 \mathrm{~g}$ (Centrifuge Avanti J-E, Beckman Coulter) for 1 hour at $20^{\circ} \mathrm{C}$. The upper soluble fraction was recovered and the macrogel (bottom fraction) was redissolved in stabilized THF and then kept at $30^{\circ} \mathrm{C}$ in the dark for 2 additional days. The solutions were then centrifuged under the same conditions as described previously. The macrogel was recovered and washed three times with ultrapure water to remove non-structuring compounds precipitated with the macrogel during centrifugation (Figure 1). After solvent evaporation, both the soluble fraction and the macrogel were finally dried at $30^{\circ} \mathrm{C}$ under a vacuum for 3 hours. The macrogel content was quantified by gravimetry.

Homogenized NR samples (A1, B1), along with their isolated soluble fractions (A2, B2) and macrogels (A3, B3), were then laminated prior to analysis. Sheets around $1.6 \mathrm{~mm}$ thick were prepared on the same two-roll mill. The roll temperature was maintained at $27^{\circ} \mathrm{C}$ and the nip was set to a minimum $(0.5 \mathrm{~mm})$. The speeds of the front and back rolls were 27.5 and $38.5 \mathrm{rpm}$, respectively.

\section{Elemental Analyses}

ICP-MS Analyses. For each sample, three S1 solutions were prepared by placing $400 \mathrm{mg}$ of a rubber sheet in $10 \mathrm{~mL}$ of a $68 \%$
$\mathrm{HNO}_{3}$ solution of ultrapure quality (SCP Science). Mineralization was then performed on a Mars5 (CEM) microwave reaction system, using three successive cycles: 1) $30 \mathrm{~min}$ at $140^{\circ} \mathrm{C}$; 2) $30 \mathrm{~min}$ at $170^{\circ} \mathrm{C}$, then 3$) 30 \mathrm{~min}$ at $190^{\circ} \mathrm{C}$. The solutions were degassed after each cycle. After mineralization, the $\mathrm{S} 1$ solutions were adjusted to $10 \mathrm{~mL}$ with ultrapure $\mathrm{HNO}_{3}(68 \%)$ to balance any evaporation, then diluted 34 times with ultrapure water to prepare S2 solutions. The S2 solutions were diluted 20 times with a $2 \% \mathrm{HNO}_{3}$ solution to prepare $\mathrm{S} 3$ solutions.

The S2 and S3 solutions were analyzed using a Thermo Scientific XSERIES 2 inductively coupled plasma mass spectrometer (Thermo Fisher Scientific, Germany), equipped with an online internal standard kit, injecting simultaneously an indium solution $\left({ }^{115} \mathrm{In}, 10 \mathrm{ppb}\right.$ in $\mathrm{HNO}_{3} 2 \%$ ) at a flow rate of $236 \mu \mathrm{L} / \mathrm{min}$. The concentrations of magnesium $\left({ }^{24} \mathrm{Mg}\right)$, phosphorus $\left({ }^{31} \mathrm{P}\right)$, potassium $\left({ }^{39} \mathrm{~K}\right)$, calcium $\left({ }^{44} \mathrm{Ca}\right)$, titanium $\left({ }^{48} \mathrm{Ti}\right)$, iron $\left({ }^{56} \mathrm{Fe}\right)$ and zinc $\left({ }^{64} \mathrm{Zn}\right)$ were measured using the collision/reaction cell in CCT1 mode (collision gas: $\mathrm{He} / \mathrm{H}_{2}$ 93\%/7\%; flow rate: $4.5 \mathrm{~mL} / \mathrm{min})$. The collision/reaction cell was used in CCT2 mode (collision gas: $\mathrm{O}_{2}$; flow rate: $0.05 \mathrm{~mL} / \mathrm{min}$ ) to determine the sulfur $\left({ }^{32} \mathrm{~S}\right)$ concentration via the determination of the mass to charge ratio $(m / z)=48$ of ${ }^{32} \mathrm{~S}^{16} \mathrm{O}^{+}$(or ${ }^{48} \mathrm{Ti}$ ), as described by Bandura et al. ${ }^{31}$ Calibration was performed using standard solutions with analyte concentrations from 0 to $400 \mathrm{ppb}$ in $2 \%$ $\mathrm{HNO}_{3}$. Three measurements were taken for each solution.

Nitrogen Contents. The Dumas method was used to determine nitrogen contents. About $600 \mathrm{mg}$ of each rubber sheet was calcined at $1100^{\circ} \mathrm{C}$ under oxygen flow. All combustion gases, excepted nitrogen oxides, were trapped in order to separate nitrogen oxides from dust, water vapor, halogen compounds and carbon oxides. Nitrogen oxides were reduced to $\mathrm{N}_{2}$ at $700^{\circ} \mathrm{C}$ under helium flow, on a copper column. The nitrogen content was then measured by catharometry, after calibration with well-known molecules such as EDTA, on a LECO Trumac $\mathrm{N}$ analyzer. Three measurements were taken for each sample.

\section{Scanning Electron Microscopy and Energy Dispersive X-ray} Spectroscopy

SEM/EDX analyses were performed on the rubber sheets using a FEI Quanta 200 FEG Environmental Scanning Electron Microscope (ESEM) equipped with an OXFORD Inca 350 Energy Dispersive X-ray (EDX) microanalyzer, under a high vacuum

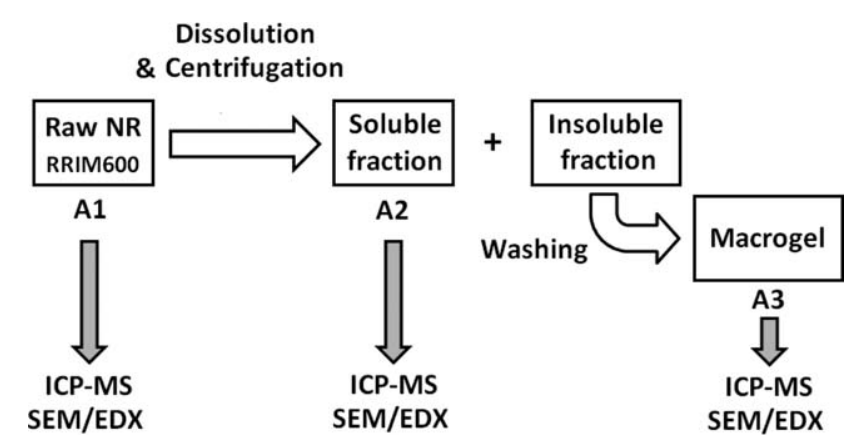

Figure 1. Protocol of separation of the soluble fraction (A2) and the macrogel (A3) of the RRIM600 NR sample (A1). The same procedure has been followed for the GT1 NR sample (B1). 
Table II. Mineral Composition of the Different Fractions of a NR Sample (TSR10 grade) Made from the Latex of Clone RRIM600 (A1), Measured by Elemental (Nitrogen Titration and ICP-MS) and SEM/EDX Analyses

\begin{tabular}{|c|c|c|c|c|}
\hline \multirow[b]{2}{*}{ RRIM600 } & \multicolumn{4}{|c|}{$\begin{array}{c}\text { Mineral concentrations } \\
(\mathrm{mg} / 100 \mathrm{~g})\end{array}$} \\
\hline & \multicolumn{2}{|c|}{$\begin{array}{l}\text { Elemental } \\
\text { analyses }\end{array}$} & \multicolumn{2}{|c|}{ SEM/EDX } \\
\hline \multicolumn{5}{|c|}{ A1: Raw NR } \\
\hline $\mathrm{N}$ & 254 & (6) & \multicolumn{2}{|c|}{$N D$} \\
\hline $\mathrm{Na}$ & & & \multicolumn{2}{|c|}{ ND } \\
\hline $\mathrm{Mg}$ & 32.7 & (2.55) & \multicolumn{2}{|c|}{$N D$} \\
\hline $\mathrm{Al}$ & & & 20 & (30) \\
\hline$P$ & 32.5 & (15.8) & 90 & (20) \\
\hline S & 33.6 & (2.02) & \multicolumn{2}{|c|}{$N D$} \\
\hline $\mathrm{Cl}$ & & & \multicolumn{2}{|c|}{$N D$} \\
\hline K & 89.6 & (7.63) & 110 & (10) \\
\hline $\mathrm{Ca}$ & 4.82 & $(0.73)$ & \multicolumn{2}{|c|}{$N D$} \\
\hline $\mathrm{Ti}$ & 0.00 & (0.00) & \multicolumn{2}{|c|}{ ND } \\
\hline $\mathrm{Fe}$ & 2.78 & (0.09) & \multicolumn{2}{|c|}{$N D$} \\
\hline $\mathrm{Zn}$ & 1.04 & (0.20) & \multicolumn{2}{|c|}{ ND } \\
\hline \multicolumn{5}{|c|}{ A2: Soluble fraction } \\
\hline $\mathrm{N}$ & 55 & 3 & \multicolumn{2}{|c|}{ ND } \\
\hline $\mathrm{Na}$ & & & \multicolumn{2}{|c|}{$N D$} \\
\hline $\mathrm{Mg}$ & 4.82 & (0.51) & \multicolumn{2}{|c|}{ ND } \\
\hline $\mathrm{Al}$ & & & \multicolumn{2}{|c|}{$N D$} \\
\hline$P$ & 10.4 & (0.53) & \multicolumn{2}{|c|}{$N D$} \\
\hline$S$ & 9.12 & (1.96) & \multicolumn{2}{|c|}{ ND } \\
\hline $\mathrm{Cl}$ & & & \multicolumn{2}{|c|}{$N D$} \\
\hline K & 14.0 & $(0.76)$ & \multicolumn{2}{|c|}{$N D$} \\
\hline $\mathrm{Ca}$ & 2.76 & (1.23) & \multicolumn{2}{|c|}{$N D$} \\
\hline $\mathrm{Ti}$ & 0.00 & (0.00) & \multicolumn{2}{|c|}{$N D$} \\
\hline $\mathrm{Fe}$ & 0.57 & $(0.14)$ & \multicolumn{2}{|c|}{$N D$} \\
\hline $\mathrm{Zn}$ & 0.84 & $(0.16)$ & & \\
\hline A3: Macro & & & & \\
\hline $\mathrm{N}$ & 743 & 14 & & \\
\hline $\mathrm{Na}$ & & & 70 & (20) \\
\hline $\mathrm{Mg}$ & 60.3 & (8.53) & 40 & (0) \\
\hline $\mathrm{Al}$ & & & & \\
\hline$P$ & 99.9 & (25.3) & 110 & (0) \\
\hline$S$ & 51.8 & (7.91) & 50 & (10) \\
\hline $\mathrm{Cl}$ & & & 30 & (40) \\
\hline K & 66.4 & (10.5) & 80 & (10) \\
\hline $\mathrm{Ca}$ & 15.3 & (1.76) & 20 & (30) \\
\hline $\mathrm{Ti}$ & 0.11 & (0.02) & & \\
\hline $\mathrm{Fe}$ & 13.3 & (1.32) & & \\
\hline $\mathrm{Zn}$ & 4.71 & (1.09) & & \\
\hline
\end{tabular}

ND, not detected.

Values in brackets are the standard deviations, obtained from 3 independent measurements.

EDX quantification was performed on surfaces of $1.96 \mathrm{~mm}^{2}(1.40 \times$ $1.40 \mathrm{~mm}^{2}$ ).
Table III. Mineral composition of the Different Fractions of a NR Sample (TSR10 grade) Made from the Latex of Clone GT1 (B1), Measured by Elemental (Nitrogen Titration and ICP-MS) and SEM/EDX Analyses

\begin{tabular}{|c|c|c|c|c|}
\hline \multirow[b]{2}{*}{ GT1 } & \multicolumn{4}{|c|}{$\begin{array}{l}\text { Mineral concentrations } \\
\quad(\mathrm{mg} / 100 \mathrm{~g})\end{array}$} \\
\hline & \multicolumn{2}{|c|}{$\begin{array}{c}\text { Elemental } \\
\text { analyses }\end{array}$} & \multicolumn{2}{|c|}{ SEM/EDX } \\
\hline \multicolumn{5}{|c|}{ B1: Raw NR } \\
\hline $\mathrm{N}$ & 296 & (2) & \multicolumn{2}{|c|}{ ND } \\
\hline $\mathrm{Na}$ & & & \multicolumn{2}{|c|}{ ND } \\
\hline $\mathrm{Mg}$ & 27.6 & (1.84) & \multicolumn{2}{|c|}{ ND } \\
\hline $\mathrm{Al}$ & & & \multicolumn{2}{|c|}{ ND } \\
\hline$P$ & 51.3 & $(4.25)$ & 60 & (10) \\
\hline S & 26.6 & (1.35) & \multicolumn{2}{|c|}{ ND } \\
\hline $\mathrm{Cl}$ & & & \multicolumn{2}{|c|}{$N D$} \\
\hline K & 65.8 & (8.35) & 70 & (10) \\
\hline $\mathrm{Ca}$ & 3.49 & $(0.76)$ & \multicolumn{2}{|c|}{ ND } \\
\hline $\mathrm{Ti}$ & 0.00 & $(0.00)$ & \multicolumn{2}{|c|}{$N D$} \\
\hline $\mathrm{Fe}$ & 5.42 & $(0.48)$ & \multicolumn{2}{|c|}{$N D$} \\
\hline $\mathrm{Zn}$ & 2.07 & (0.10) & \multicolumn{2}{|c|}{ ND } \\
\hline \multicolumn{5}{|c|}{ B2: Soluble fraction } \\
\hline $\mathrm{N}$ & 122 & (2) & \multicolumn{2}{|c|}{ ND } \\
\hline $\mathrm{Na}$ & & & \multicolumn{2}{|c|}{ ND } \\
\hline $\mathrm{Mg}$ & 6.24 & (0.73) & \multicolumn{2}{|c|}{ ND } \\
\hline Al & & & \multicolumn{2}{|c|}{ ND } \\
\hline$P$ & 14.4 & (1.16) & \multicolumn{2}{|c|}{ ND } \\
\hline S & 11.5 & (2.36) & \multicolumn{2}{|c|}{ ND } \\
\hline $\mathrm{Cl}$ & & & \multicolumn{2}{|c|}{ ND } \\
\hline K & 17.7 & $(0.94)$ & \multicolumn{2}{|c|}{ ND } \\
\hline $\mathrm{Ca}$ & 2.25 & $(0.45)$ & \multicolumn{2}{|c|}{ ND } \\
\hline $\mathrm{Ti}$ & 0.00 & $(0.00)$ & \multicolumn{2}{|c|}{ ND } \\
\hline $\mathrm{Fe}$ & 1.02 & $(0.85)$ & & \\
\hline $\mathrm{Zn}$ & 1.09 & (0.30) & & \\
\hline B3: M & & & & \\
\hline $\mathrm{N}$ & 1181 & (19) & & \\
\hline $\mathrm{Na}$ & & & 220 & (50) \\
\hline $\mathrm{Mg}$ & 50.8 & (3.84) & 50 & (10) \\
\hline $\mathrm{Al}$ & & & & \\
\hline$P$ & 152 & (30.1) & 230 & (30) \\
\hline$S$ & 129 & (22.5) & 160 & (20) \\
\hline $\mathrm{Cl}$ & & & & \\
\hline K & 28.0 & $(4.14)$ & & \\
\hline $\mathrm{Ca}$ & 13.0 & $(1.06)$ & 20 & (30) \\
\hline $\mathrm{Ti}$ & 0.11 & $(0.01)$ & & \\
\hline $\mathrm{Fe}$ & 33.7 & (3.20) & & \\
\hline $\mathrm{Zn}$ & 3.51 & (1.55) & & \\
\hline
\end{tabular}

ND: not detected.

Values in brackets are the standard deviations, obtained from three independent measurements.

EDX quantification was performed on surfaces of $1.96 \mathrm{~mm}^{2}(1.40 \times$ $1.40 \mathrm{~mm}^{2}$ ). 

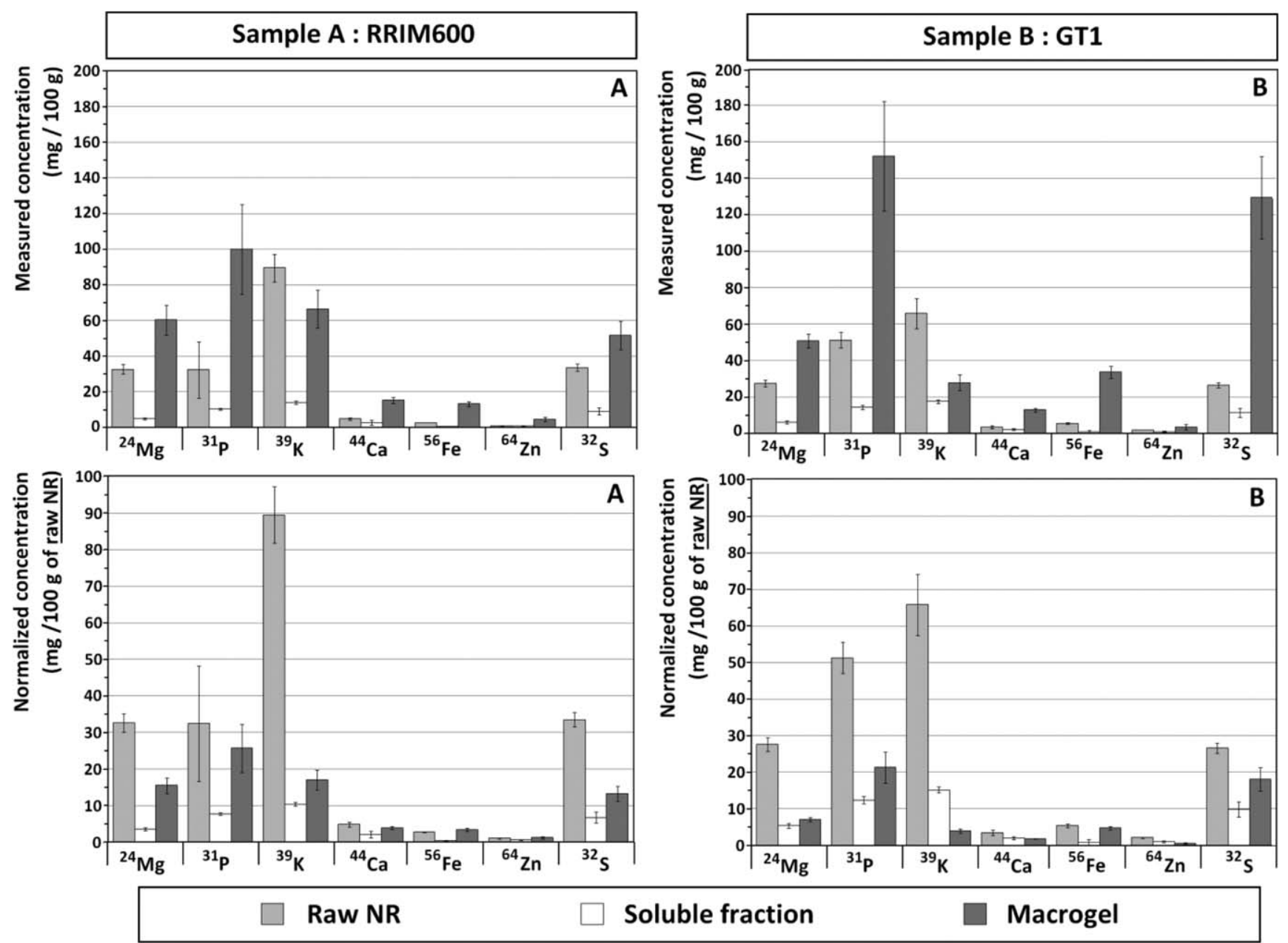

Figure 2. Measured and normalized mineral concentrations of two NR samples (TSR10 grade) made from the latex of clones RRIM600 (A1) and GT1 (B1), and their macrogel and soluble fractions, determined by ICP-MS analyses. Normalized concentrations (in mg/100 g of raw NR) were calculated using the measured macrogel contents.

and at room temperature. A thin carbon film was first deposited on the investigated surfaces in order to make the samples conductive and to prevent any thermal degradation caused by the electron beam. The topography of the rubber sheets was characterized using the secondary electron signal. The backscattered electron signal was used to locate the heaviest elements. The accelerating voltage was $15 \mathrm{kV}$. EDX microanalyses were performed to determine the nature of the minerals present in some specific areas of the testing surfaces. The acquisition time was $30 \mathrm{~s}$, at a count rate of $20 \mathrm{kcps}$. An XPP correction algorithm was used for the quantitative analyses. The detection threshold for peak identification was 2 sigmas. The mean elemental composition of the rubber sheets was also estimated by EDX spectroscopy. Surfaces of $1.96 \mathrm{~mm}^{2}\left(1.40 \times 1.40 \mathrm{~mm}^{2}\right)$ were analyzed and three replications were performed.

\section{RESULTS AND DISCUSSION}

\section{ICP-MS Analyses}

The mineral compositions of NR samples made from the latex of clones RRIM600 (A1) and GT1 (B1) were measured by ICP-MS (Tables II and III, Figure 2). Both NR samples showed large concentrations of ${ }^{39} \mathrm{~K}$ (RRIM600: $89.6 \mathrm{mg} / 100 \mathrm{~g}$; GT1: $65.8 \mathrm{mg} /$ 100g), ${ }^{31}$ P (RRIM600: $32.5 \mathrm{mg} / 100 \mathrm{~g}$; GT1: $51.3 \mathrm{mg} / 100 \mathrm{~g}$ ) and ${ }^{24} \mathrm{Mg}$ (RRIM600: $32.7 \mathrm{mg} / 100 \mathrm{~g}$; GT1: $27.6 \mathrm{mg} / 100 \mathrm{~g}$ ). Those three elements were found to be the most concentrated among the analytes, in agreement with the literature (Table I). Except for phosphorus, it was found that the RRIM600 sample (A1) had higher mineral concentrations than the GT1 sample (B1), which was in accordance with previous results. ${ }^{24}$ Both NR samples also showed much lower concentrations of ${ }^{56} \mathrm{Fe}(2.8-$ $5.4 \mathrm{mg} / 100 \mathrm{~g}),{ }^{44} \mathrm{Ca}(3.5-4.8 \mathrm{mg} / 100 \mathrm{~g})$ and ${ }^{64} \mathrm{Zn}(1.0-2.1 \mathrm{mg} /$ $100 \mathrm{~g})$. No ${ }^{48} \mathrm{Ti}$ was found using the collision/reaction cell in CCT1 mode for the two raw NR samples, indicating that this analyte could be used in CCT2 mode to determine ${ }^{32} \mathrm{~S}$ concentrations (Tables II and III). Sulfur (RRIM600: $33.6 \mathrm{mg} / 100 \mathrm{~g}$; GT1: $26.6 \mathrm{mg} / 100 \mathrm{~g}$ ) was found to be the fourth most abundant element among the studied analytes.

The soluble and the insoluble (macrogel) fractions of both NR samples were extracted. As minerals are insoluble in organic solvent, they may sediment in the insoluble fraction during centrifugation. Ultrapure water was used to wash the macrogel of both NR samples and eliminate non-structuring compounds. The soluble fraction and the washed macrogel of both samples 
Table IV. Normalized Mineral Concentrations (in mg/100 g of Raw NR) of the Different Fractions of a NR Sample (TSR10 grade) Made from the Latex of Clone RRIM600 (A1), and Estimated Material Losses Occurring during the Macrogel Washing Steps

\begin{tabular}{|c|c|c|c|c|c|c|c|c|}
\hline \multirow{4}{*}{$\begin{array}{l}\text { RRIM600 } \\
\mathrm{N}\end{array}$} & \multicolumn{7}{|c|}{ Concentrations (mg/100 g of raw NR) } & \multirow{4}{*}{$\begin{array}{l}\text { Material } \\
\text { losses (\%) } \\
(\mathrm{A} 2+\mathrm{A} 3-\mathrm{A} 1) / \mathrm{A} 1 \\
-9 \%\end{array}$} \\
\hline & \multicolumn{2}{|c|}{ Raw NR } & \multirow{2}{*}{\multicolumn{2}{|c|}{$\begin{array}{l}\begin{array}{c}\text { Soluble fraction } \\
(74.3 \% \text { of } A 1)\end{array} \\
\text { A2 }\end{array}$}} & \multirow{2}{*}{\multicolumn{2}{|c|}{$\begin{array}{c}\text { Macrogel }(25.7 \% \\
\text { of } A 1)\end{array}$}} & \multirow{3}{*}{$\begin{array}{l}\text { All fractions } \\
(100 \% \text { of } A 1) \\
A 2+A 3 \\
232\end{array}$} & \\
\hline & & & & & & & & \\
\hline & 254 & (6) & 41 & (2) & 191 & (3) & & \\
\hline${ }^{24} \mathrm{Mg}$ & 32.7 & (2.55) & 3.58 & (0.38) & 15.5 & (2.19) & 19.1 & $-42 \%$ \\
\hline${ }^{31} \mathrm{P}$ & 32.5 & (15.8) & 7.76 & $(0.40)$ & 25.7 & (6.50) & 33.4 & $3 \%$ \\
\hline${ }^{39} \mathrm{~K}$ & 89.6 & (7.63) & 10.4 & (0.57) & 17.1 & (2.70) & 27.5 & $-69 \%$ \\
\hline${ }^{44} \mathrm{Ca}$ & 4.82 & (0.73) & 2.05 & (0.91) & 3.92 & $(0.45)$ & 5.97 & $24 \%$ \\
\hline${ }^{56} \mathrm{Fe}$ & 2.78 & (0.09) & 0.42 & (0.10) & 3.42 & (0.34) & 3.84 & $38 \%$ \\
\hline${ }^{64} \mathrm{Zn}$ & 1.04 & (0.20) & 0.62 & (0.12) & 1.21 & (0.28) & 1.83 & $77 \%$ \\
\hline${ }^{32} \mathrm{~S}$ & 33.6 & (2.02) & 6.77 & (1.46) & 13.3 & (2.03) & 20.1 & $-40 \%$ \\
\hline
\end{tabular}

Values in brackets are the standard deviations, obtained from three independent measurements.

were then analyzed by ICP-MS (Tables II and III). Mineral concentrations were very low in both soluble fractions (A2, B2) compared to their respective raw NR samples (A1, B1) (Figure 2). On the other hand, the two macrogels (A3, B3) showed the highest concentrations of ${ }^{24} \mathrm{Mg},{ }^{31} \mathrm{P},{ }^{44} \mathrm{Ca},{ }^{56} \mathrm{Fe},{ }^{64} \mathrm{Zn}$ and ${ }^{32} \mathrm{~S}$. Those elements were clearly concentrated in the macrogel during extraction. Titanium was also detected $(0.1 \mathrm{mg} / 100 \mathrm{~g})$ in both macrogels. As regards the $\mathrm{K}$ atoms, higher concentrations were measured for both raw NR samples (Tables II and III), indicating evident mineral loss during macrogel extraction and washing. It is worth noting that the two macrogels did not have the same mineral concentrations: the macrogel of the GT1 sample (B3) had higher concentrations of ${ }^{31} \mathrm{P},{ }^{32} \mathrm{~S}$ and ${ }^{56} \mathrm{Fe}$ than the macrogel of the RRIM600 sample (A3).

The macrogel contents were $25.7 \%$ and $14.0 \%(\mathrm{w} / \mathrm{w})$ for the samples made from the latex of clones RRIM600 (A1) and GT1 (B1) respectively. The mineral concentrations of the isolated fractions were normalized by their respective proportions in the raw NR samples (Tables IV and V). The calculated concentrations (in $\mathrm{mg} / 100 \mathrm{~g}$ of raw NR) were used to estimate the mineral quantities lost during macrogel washing. The calculated differences between the recovered (macrogel + soluble fraction) and the initial (raw NR) concentrations were found to be dependent on the sample, but also on the element. First, some positive differences were observed for minerals with low concentrations. For example, a $\mathrm{Zn}$ overage of $77 \%$ was calculated for the RRIM600 samples (A1), but it only corresponded to a difference of $0.8 \mathrm{mg} / 100 \mathrm{~g}$ of raw NR, which could be explained by inaccuracies on the ICP-MS measurements but also on the macrogel content determination. So, for trace elements like $\mathrm{Zn}$ or Fe, it is reasonable to consider that no mineral was lost when the calculated difference was positive. Nevertheless, for both NR samples, large ${ }^{39} \mathrm{~K}(\sim-70 \%)$ and ${ }^{24} \mathrm{Mg}$ (RRIM600: $-42 \%$; GT1: $-55 \%$ ) losses were calculated. The RRIM600 samples (A1) also showed a large loss of ${ }^{32} \mathrm{~S}(-40 \%)$. For the GT1 sample (B1), significant quantities of ${ }^{31} \mathrm{P}(-34 \%)$ were also missing. It is quite clear

Table V. Normalized Mineral Concentrations (in mg/100 g of raw NR) of the Different Fractions of a NR Sample (TSR10 grade) Made from the Latex of Clone GT1 (B1), and Estimated Material Losses Occurring during the Macrogel Washing Steps

\begin{tabular}{|c|c|c|c|c|c|c|c|c|}
\hline \multirow[b]{3}{*}{ GT1 } & \multicolumn{7}{|c|}{ Concentrations (mg/100 g of raw NR) } & \multirow{4}{*}{$\begin{array}{l}\text { Material } \\
\text { losses (\%) } \\
(\mathrm{B} 2+\mathrm{B} 3-\mathrm{B} 1) / \mathrm{B} 1 \\
-9 \%\end{array}$} \\
\hline & \multicolumn{2}{|c|}{ Raw NR } & \multicolumn{2}{|c|}{$\begin{array}{l}\text { Soluble fraction } \\
\text { (86.0\% of B1) }\end{array}$} & \multicolumn{2}{|c|}{$\begin{array}{c}\text { Macrogel }(14.0 \% \\
\text { of } \mathrm{B} 1)\end{array}$} & \multirow{2}{*}{$\begin{array}{l}\text { All fractions } \\
\text { (100\% of B1) } \\
\text { B2 + B3 }\end{array}$} & \\
\hline & & & & & & & & \\
\hline $\mathrm{N}$ & 296 & (2) & 105 & (2) & 165 & (3) & 270 & \\
\hline${ }^{24} \mathrm{Mg}$ & 27.6 & (1.84) & 5.37 & (0.63) & 7.11 & $(0.54)$ & 12.5 & $-55 \%$ \\
\hline${ }^{31} \mathrm{P}$ & 51.3 & (4.25) & 12.4 & $(1.00)$ & 21.3 & (4.22) & 33.7 & $-34 \%$ \\
\hline${ }^{39} \mathrm{~K}$ & 65.8 & (8.35) & 15.2 & $(0.81)$ & 3.93 & (0.58) & 19.1 & $-71 \%$ \\
\hline${ }^{44} \mathrm{Ca}$ & 3.49 & $(0.76)$ & 1.94 & (0.38) & 1.81 & (0.15) & 3.75 & $7 \%$ \\
\hline${ }^{56} \mathrm{Fe}$ & 5.42 & (0.48) & 0.88 & $(0.73)$ & 4.71 & $(0.45)$ & 5.59 & $3 \%$ \\
\hline${ }^{64} \mathrm{Zn}$ & 2.07 & (0.10) & 0.94 & $(0.26)$ & 0.49 & $(0.22)$ & 1.43 & $-31 \%$ \\
\hline${ }^{32} \mathrm{~S}$ & 26.6 & (1.35) & 9.89 & (2.03) & 18.1 & (3.15) & 28.0 & $5 \%$ \\
\hline
\end{tabular}

Values in brackets are the standard deviations, obtained from 3 independent measurements. 

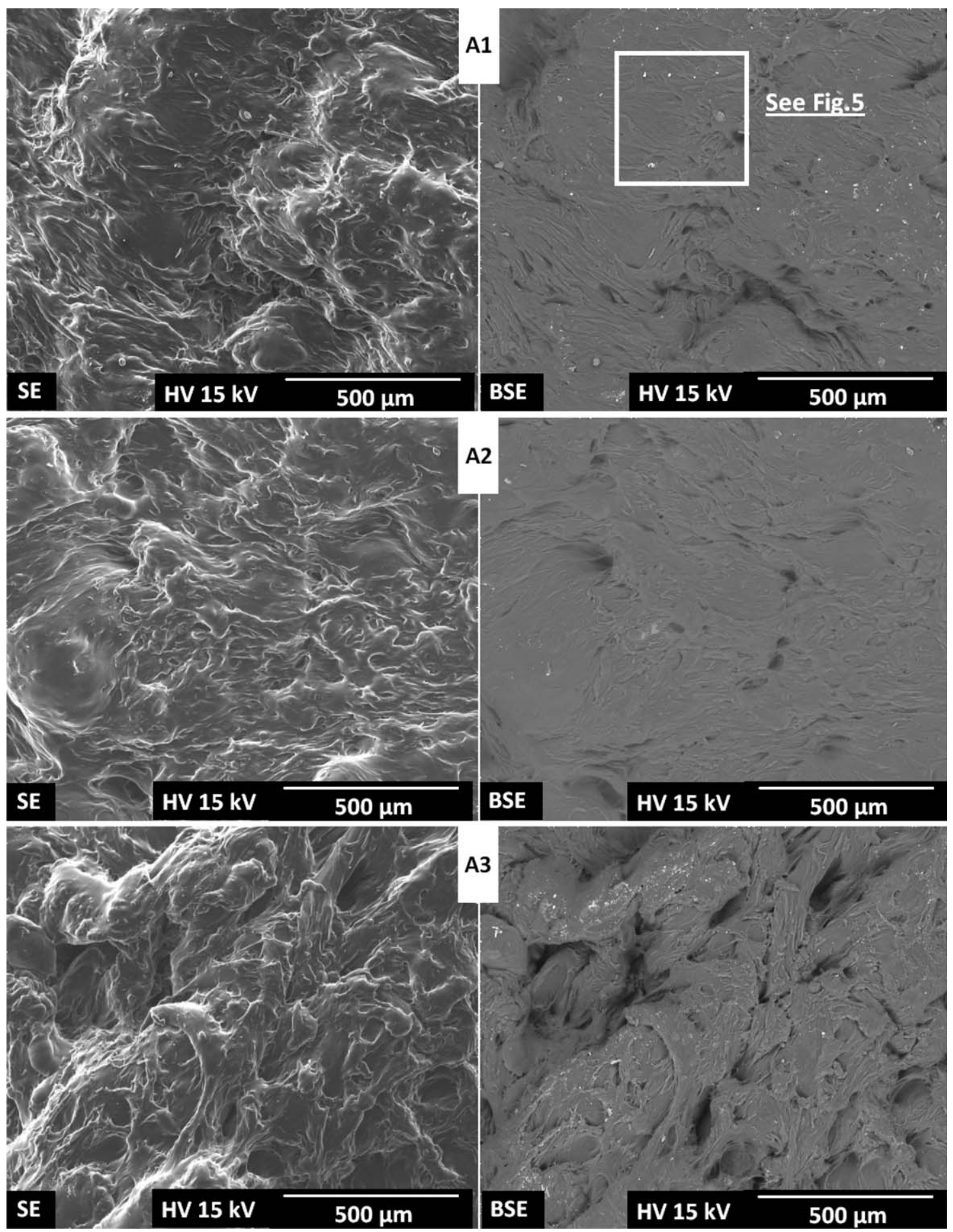

Figure 3. SEM observations (mag. 100x) of the raw RRIM600 sample (A1), and the corresponding soluble fraction (A2) and macrogel (A3), using the secondary electron (SE; left) and the backscattered electron (BSE; right) modes.

that those missing minerals, eliminated during the macrogel washing steps with ultrapure water, do not structure the macrogel of NR. It is worth noting that, except for sulfur, the mineral losses were found to be lower for the RRIM600 sample (A1), which displayed the highest macrogel content (Tables IV and V). Minerals could be associated with the macrogel and take part in its structuring, or could only be trapped in the cis-1,4- polyisoprene matrix. Likewise, the minerals found in the soluble fractions (Tables II and III) could be associated with the microaggregates making up the microgel.

\section{Nitrogen Contents}

Nitrogen contents were quantified using the Dumas method to estimate the concentration of proteins and polypeptides present 


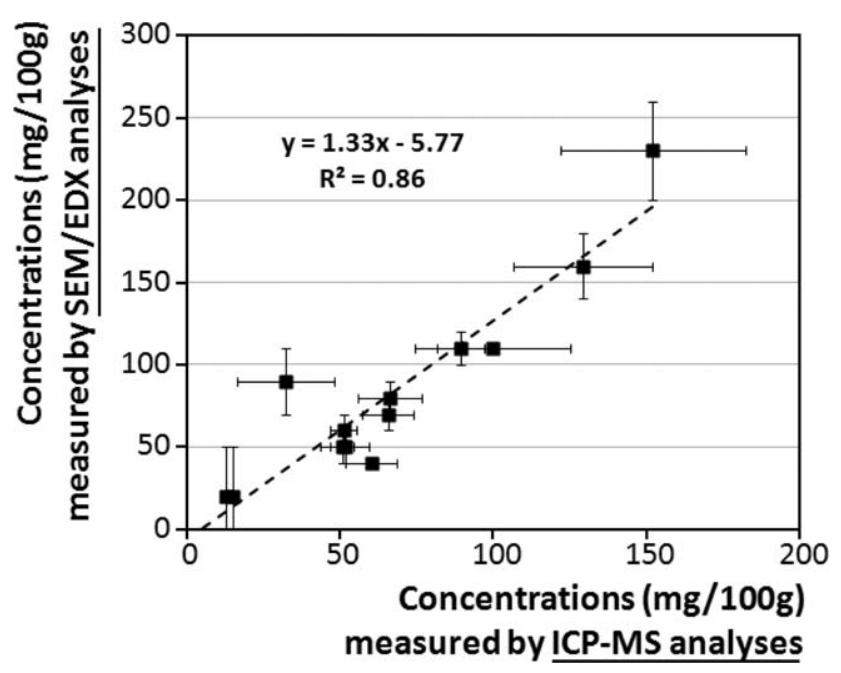

Figure 4. Correlation obtained between the mineral concentrations measured by SEM/EDX and ICP-MS analyses. EDX quantification was performed on surfaces of $1.96 \mathrm{~mm}^{2}\left(1.40 \times 1.40 \mathrm{~mm}^{2}\right)$.

in each rubber sheet. ${ }^{18,32}$ Nitrogen was found to represent $0.25 \%$ (A1: RRIM600) and $0.30 \% \mathrm{w} / \mathrm{w}$ (B1: GT1) of the raw NR samples (Tables II and III). For both soluble fractions, nitrogen concentrations were very low (A2: $0.06 \% \mathrm{w} / \mathrm{w} ; \mathrm{B} 2$ : $0.12 \% \mathrm{w} / \mathrm{w})$ compared to the corresponding raw NR samples. The highest nitrogen contents were measured for both macrogels: $0.74 \% \mathrm{w} / \mathrm{w}$ for the RRIM600 macrogel (A3) and 1.18\% w/ $\mathrm{w}$ for the GT1 macrogel (B3). Those results indicate that proteins are mainly concentrated in the macrogel of NR, in accordance with the literature. ${ }^{6,33}$ It is worth noting that the nitrogen contents of the soluble fraction (A2) and the macrogel (A3) of the RRIM600 sample were lower than those of the GT1 fractions.

As for minerals, the measured nitrogen contents were normalized by the respective proportions of each fraction in the corresponding raw NR sample (Tables IV and V). For both NR samples, a nitrogen loss of $9 \%$ was calculated, and was assumed to be eliminated during the washing of the macrogels. These material losses could be attributed to non-structuring hydrophilic proteins, which are insoluble in organic solvent.

\section{SEM/EDX Analyses}

The rubber sheets were studied by SEM/EDX. First, the topography of the samples was characterized using the secondary electron (SE) signal. No major difference was observed for surface roughness between the rubber sheets obtained from raw NR samples (A1, B1), and their soluble fraction (A2, B2) or macrogel (A3, B3) (Figure 3). Energy dispersive X-ray (EDX) analyses were performed to estimate the mean elemental composition of each sample (Tables II and III). Different mineral atoms were detected depending on the samples. For both raw NR samples (A1, B1), phosphorus (RRIM600 : $90 \mathrm{mg} / 100 \mathrm{~g}$; GT1 : $60 \mathrm{mg} / 100 \mathrm{~g}$ ), and potassium (RRIM600 : $110 \mathrm{mg} / 100 \mathrm{~g}$; GT1 : $70 \mathrm{mg} / 100 \mathrm{~g}$ ) were detected. The RRIM600 sample (A1) also showed the presence of aluminium $(20 \mathrm{mg} / 100 \mathrm{~g})$. The other minerals present in the NR samples were not detected, indicating that the corresponding concentrations were under the detection thresholds of EDX spectroscopy. In the same way, no mineral elements were detected in either soluble fraction (A2, B2). The macrogel samples (A3, B3) showed the presence of $\mathrm{Na}, \mathrm{Mg}, \mathrm{P}, \mathrm{S}$ and $\mathrm{Ca}$. Chlorine $(\mathrm{Cl})$ and $\mathrm{K}$ atoms were also found in the macrogel of the RRIM600 sample (A3). Except for $\mathrm{K}$, all the mineral concentrations measured for the macrogel samples were higher than those of the corresponding raw NR samples, indicating a concentration of minerals in the macrogel of NR. It is worth noting that these SEM/EDX results were quite correlated with the ICP-MS results $\left(R^{2}=0.86\right.$, Figure 4$)$. The differences observed between the two methods can be explained by the higher detection thresholds of EDX spectroscopy. It is also important to mention that light elements are hardly quantifiable by EDX spectroscopy. ${ }^{34}$ For example, nitrogen atoms, which accounted for $0.25 \%-0.30 \% \mathrm{w} / \mathrm{w}$ of the raw NR samples and $0.74 \%-1.18 \% \mathrm{w} / \mathrm{w}$ of the macrogels (Tables II and III), were not detected (Figure 5). Moreover, EDX quantification was performed on unpolished surfaces to avoid material surface deterioration. However, these results indicated that SEM/EDX could be used to quickly estimate some mineral concentrations (e.g. P or K) in NR sheets.

The backscattered electrons (BSE mode) were used as information about mineral distribution (Figure 3). Heavy chemical elements with high atomic numbers are known to backscatter electrons stronger than lighter elements, and to appear brighter on SEM images. Consequently, the cis-1,4-polyisoprene matrix, containing carbon and hydrogen atoms, was colored in gray and the heaviest elements were colored in white. Inhomogeneously distributed white areas, containing minerals, were found on the surface of the NR sample made from RRIM600 latex (A1, Figure 3, BSE mode). The white mineral areas were found to be very limited for the RRIM600 soluble fraction (A2, Figure 3 ) as only a few were observed. On the other hand, the RRIM600 macrogel (A3, Figure 3) showed many mineral areas, compared to the raw NR sample (A1). The same observations were made for the rubber sheets obtained from the GT1 samples (B1-B3). The dimensions of these white areas were in the range of $15-25 \mu \mathrm{m}$ for the largest and $1-5 \mu \mathrm{m}$ for the smallest (Figure 6).

The composition of the white mineral areas observed on the surface of both raw NR samples in BSE mode (Figure 6) was

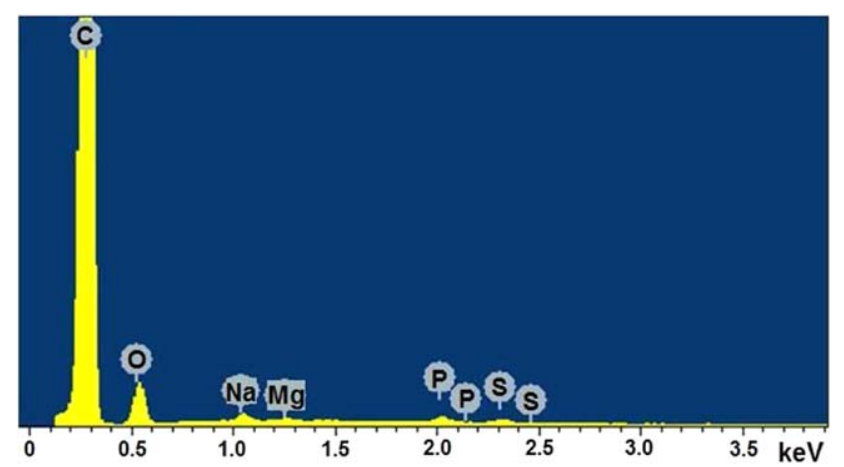

Figure 5. EDX spectrum of the macrogel of the RRIM60 sample (B3). [Color figure can be viewed in the online issue, which is available at wileyonlinelibrary.com.] 

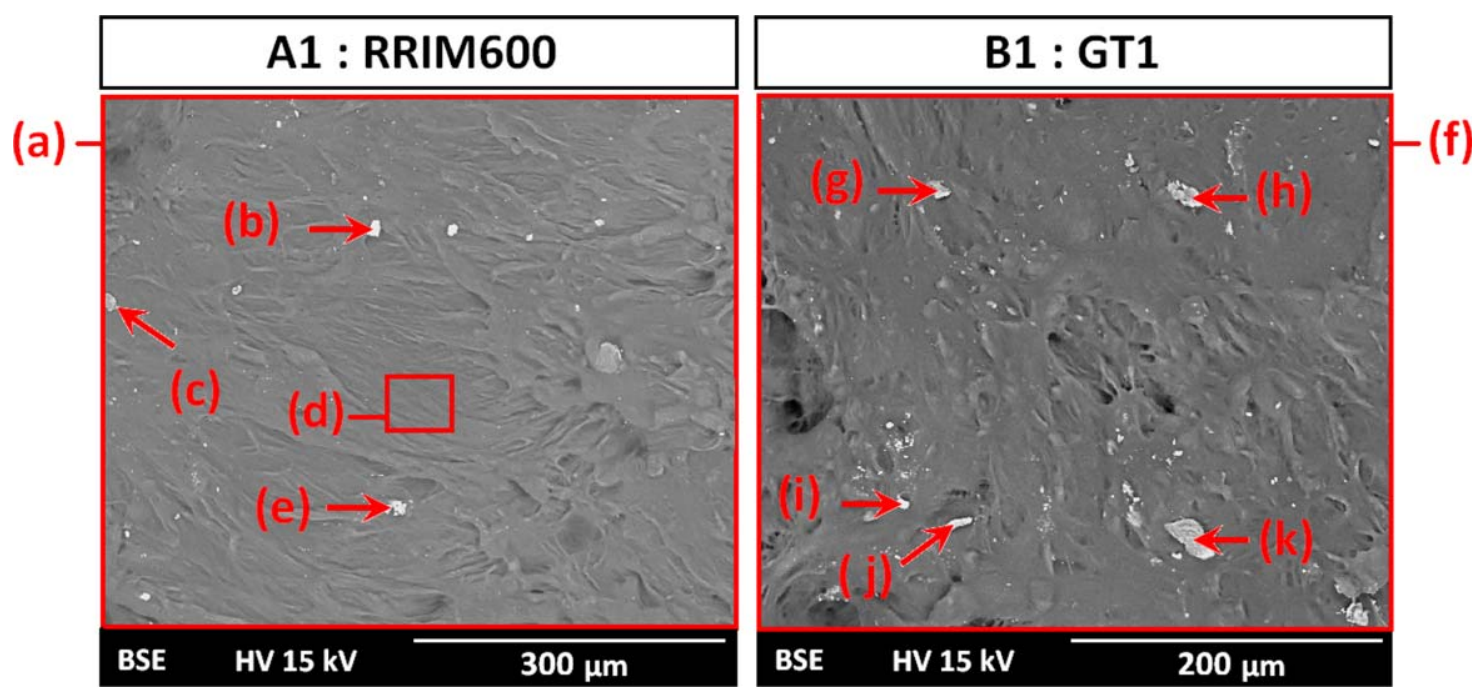

Figure 6. SEM observations (BSE mode) of the surface of the raw RRIM600 (A1) and GT1 (B1) samples. EDX microanalyses were performed to determine the composition of the areas (a) to (k) (See Table VI). [Color figure can be viewed in the online issue, which is available at wileyonlinelibrary.com.]

found to be highly variable, using EDX spectroscopy (Table VI). Indeed, several mineral oxides can be found on the surface of NR samples. For example, $\mathrm{CaCO}_{3}$ (b), $\mathrm{P}_{4} \mathrm{O}_{10}$ (e) and $\mathrm{SiO}_{2}$ (i) were clearly identified (Table VI). Other areas were found to be composed of a mixture of several oxides (e.g. areas g, h and k). In those areas, large concentrations of nitrogen $(11-41 \% \mathrm{w} / \mathrm{w})$ were detected, indicating high protein content locally. It is worth noting that $\mathrm{KCl}$ and $\mathrm{NaCl}$ crystals (c, g-k) were also observed in different mineral areas. Titanium (Ti), iron ( $\mathrm{Fe})$ and even fluorine (F) were detected in some mineral areas of the GT1 samples (A1). Equivalent compositions (Table VII) were measured for the mineral areas present on the surface of the macrogel (A3, Figure 7) and the soluble fraction (A2, Figure 8) of the RRIM600 sample. Chloride crystals and several oxides were found. The macrogel sample showed a large quantity of $\mathrm{ZnO}$ (l-n, p-r), while iron oxides (s) were found in the soluble fraction.

The mineral areas observed in BSE mode were also visible using the secondary electron signal (SE) and corresponded to aggregates present on the surface of the samples (Figure 7). For example, aggregates of about $5 \mu \mathrm{m}$ ( $\mathrm{n}, \mathrm{o}$; Figure 7) were

Table VI. Elemental Composition Determined by SEM/EDX of Some Areas of the Surface of Both Raw RRIM600 (A1) and GT1 (B1) Samples (See Figure 6)

Composition (\% w/w) of the areas (a) to (k) measured by SEM/EDX (See Figure 6)

\begin{tabular}{|c|c|c|c|c|c|c|c|c|c|c|c|}
\hline & \multicolumn{5}{|c|}{ A1: RRIM600 - Raw NR } & \multicolumn{6}{|c|}{ B1: GT1 - Raw NR } \\
\hline & (a) & (b) & (c) & (d) & (e) & $(f)$ & (g) & (h) & (i) & (j) & $(k)$ \\
\hline $\mathrm{C}$ & 95.44 & - & - & - & - & 95.26 & - & - & - & - & - \\
\hline $\mathrm{N}$ & - & - & 11.85 & - & - & - & 22.99 & 23.44 & - & - & 40.45 \\
\hline 0 & 4.36 & 49.76 & 56.89 & 97.13 & 66.35 & 4.59 & 62.89 & 56.72 & 60.07 & - & 50.18 \\
\hline$F$ & - & - & - & - & - & - & - & - & 1.76 & - & - \\
\hline $\mathrm{Na}$ & - & - & 2.99 & - & 1.41 & - & 1.48 & 2.71 & - & - & 2.24 \\
\hline $\mathrm{Mg}$ & - & - & - & - & 0.87 & - & 0.26 & 0.31 & 5.23 & - & 0.16 \\
\hline $\mathrm{Al}$ & - & 1.36 & - & - & - & - & 0.51 & 0.31 & 5.27 & 0.37 & 0.27 \\
\hline $\mathrm{Si}$ & - & - & 1.74 & - & - & - & 1.17 & 0.66 & 18.19 & 2.42 & 0.19 \\
\hline $\mathrm{P}$ & 0.10 & - & - & - & 27.79 & 0.07 & 0.34 & - & - & - & 0.22 \\
\hline$S$ & - & - & 2.88 & - & 0.33 & - & 1.31 & 2.98 & - & 13.51 & 1.16 \\
\hline $\mathrm{Cl}$ & - & - & 12.79 & - & 0.21 & - & 1.97 & 7.48 & - & 35.96 & 2.51 \\
\hline K & 0.10 & - & 8.21 & 2.87 & 2.47 & 0.08 & 1.28 & 3.25 & 3.75 & 19.75 & 2.11 \\
\hline $\mathrm{Ca}$ & - & 48.87 & 2.65 & - & 0.56 & - & 1.94 & 1.74 & 1.68 & 22.67 & 0.51 \\
\hline $\mathrm{Ti}$ & - & - & - & - & - & - & 2.17 & 0.35 & 0.35 & 5.31 & - \\
\hline $\mathrm{Fe}$ & - & - & - & - & - & - & 1.65 & - & 3.71 & - & - \\
\hline
\end{tabular}

Except for the areas (a) and (f), the carbon concentrations were set at $0 \%$ for a better understanding. 
Table VII. Elemental Composition Determined by SEM/EDX of Some Areas of the Surface of the Macrogel (A3, Figure 7) and the Soluble Fraction (A2, Figure 8) of the RRIM600 NR Sample

\begin{tabular}{|c|c|c|c|c|c|c|c|c|c|c|c|c|}
\hline \multicolumn{13}{|c|}{ Composition (\% $w / w)$ of the areas $(I)$ to $(w)$ measured by SEM/EDX } \\
\hline & \multicolumn{7}{|c|}{ A3: RRIM600 - Macrogel } & \multicolumn{5}{|c|}{ A2: RRIM600 - Soluble fraction } \\
\hline & \multicolumn{4}{|c|}{ Figure 7} & \multicolumn{3}{|c|}{ Figure 7} & \multicolumn{5}{|c|}{ Figure 8} \\
\hline & (l) & $(\mathrm{m})$ & (n) & (о) & (p) & (q) & $(r)$ & (s) & $(t)$ & (u) & (v) & $(w)$ \\
\hline C & - & - & - & - & - & - & - & - & - & - & - & - \\
\hline $\mathrm{N}$ & - & - & - & - & - & - & - & - & - & - & - & - \\
\hline 0 & 25.02 & 46.93 & - & 9.82 & 51.31 & 45.15 & 32.73 & 66.18 & 70.76 & - & 66.97 & 65.61 \\
\hline $\mathrm{F}$ & - & - & - & - & - & - & - & - & - & - & - & 1.23 \\
\hline $\mathrm{Na}$ & - & - & 21.35 & 20.23 & - & - & - & - & - & 6.16 & - & - \\
\hline $\mathrm{Mg}$ & 0.76 & 0.45 & - & - & - & 0.32 & 0.42 & - & - & - & - & 0.29 \\
\hline $\mathrm{Al}$ & - & - & - & - & 0.34 & - & 0.31 & - & - & - & - & - \\
\hline $\mathrm{Si}$ & - & - & - & - & - & 0.21 & 0.45 & - & - & - & - & 0.17 \\
\hline$P$ & - & - & - & - & - & - & 0.31 & - & - & - & - & - \\
\hline S & 1.01 & - & - & 0.31 & 0.44 & 0.24 & 0.25 & - & - & - & - & - \\
\hline $\mathrm{Cl}$ & 3.24 & 0.90 & 53.14 & 47.20 & 2.91 & 2.79 & 13.70 & 0.77 & 0.54 & 48.48 & - & - \\
\hline K & 2.29 & 0.60 & 23.37 & 22.47 & 1.45 & 0.85 & 3.11 & 0.62 & 0.59 & 45.29 & - & - \\
\hline $\mathrm{Ca}$ & - & 0.50 & - & - & - & - & 0.85 & 0.51 & 27.59 & - & 33.03 & 32.70 \\
\hline $\mathrm{Ti}$ & - & - & - & - & - & - & - & - & - & - & - & - \\
\hline $\mathrm{Fe}$ & - & - & - & - & - & - & - & 31.92 & - & - & - & - \\
\hline $\mathrm{Zn}$ & 67.69 & 50.62 & 2.14 & - & 43.55 & 50.44 & 47.85 & - & 0.52 & - & - & - \\
\hline
\end{tabular}

The carbon concentrations were set at $0 \%$ for a better understanding.

observed on the surface of the RRIM600 macrogel (A3) and were mostly composed of $\mathrm{NaCl}$ and $\mathrm{KCl}$ (Table VII). The mineral oxides were concentrated in smaller aggregates $(0.5-3 \mu \mathrm{m})$, also visible on the rubber sheet surfaces.

SEM/EDX analyses revealed that minerals were inhomogeneously distributed in the cis-1,4-polyisoprene matrix, for all the samples tested (Figure 3). Some minerals were found to be concentrated in micron-sized aggregates, easily observable using the backscattered electron (BSE) signal. The quantities of mineral aggregates were higher for macrogels (A3, B3) and lower for the soluble fractions (A2, B2) compared to the corresponding raw NR samples (A1, B1). The mineral composition of those aggregates was found to be very variable (Tables VI and VII). Chloride crystals $(\mathrm{NaCl}$ and $\mathrm{KCl})$ were observed. Other aggregates were mainly composed of $\mathrm{Ca}, \mathrm{P}, \mathrm{Si}$ and $\mathrm{Zn}$ oxides. Aggregates with complex compositions (mixtures of several oxides) were also observed and showed the existence of $\mathrm{Mg}, \mathrm{Al}, \mathrm{Ti}$ and $\mathrm{Fe}$ oxides.

Those mineral aggregates were initially present in the raw NR samples (Figure 6). The fact that the mineral concentrations in the soluble fractions were very low (Tables II and III) indicated that most of the mineral aggregates of NR were insoluble in organic solvents, and were concentrated in the macrogel during centrifugation (Figure 3, Tables II and III). The macrogel washing steps led to major loss of some mineral concentrations (Tables IV and V). The highest mineral loss was calculated for the $\mathrm{K}$ atoms. The large quantity of $\mathrm{KCl}$ aggregates observed on the surface of each sample (Figures 6,7 ), which are known to be highly soluble in water, might explain the higher $\mathrm{K}$ loss.
A minor fraction of minerals was also found in the soluble fractions (Figure 8). Given that the microgel of NR samples can account for more than $30 \% \mathrm{w} / \mathrm{w},{ }^{35,36}$ it is clear that the microaggregates present in NR are not composed of minerals only, which account for $0.2 \%$ of the total weight of NR. ${ }^{1,2}$ However, the mineral aggregates observed in the soluble fractions could be associated with the microgel phase of NR, according to previous results. ${ }^{16,17}$ Rippel et al. identified calcium as a major cross-link agent in the structure of NR microgel. ${ }^{16}$ It should be remembered that calcium oxides were found in the soluble fraction of the RRIM600 sample (A2, Figure 8).

As regards the macrogel, the inhomogeneous mineral distribution (Figure 7) suggested that ionic bonds are not the main interactions involved in macrogel structure. Moreover, part of the minerals can be removed by washing the macrogel with ultrapure water (Tables IV and V). The gray background (BSE signal) and the EDX analyses showed that the macrogel phase was mostly composed of a carbon-oxygen matrix. Given that nitrogen atoms are hardly detected in EDX spectroscopy, it is quite plausible that physical interactions between proteins and the cis-1,4-polyisoprene macromolecules are responsible for the macrogel structure. ${ }^{32}$ Indeed, proteins were found to be concentrated in the macrogel samples (Tables II and III).

Concerning the origin of the mineral elements, some of them are naturally present in the latex of Hevea brasiliensis (Table I) and are retained in the processed NR sample. However, our studies showed the existence of chloride salt $(\mathrm{NaCl}, \mathrm{KCl})$ and sand $\left(\mathrm{SiO}_{2}\right)$ in the raw NR samples (Table VI). Those 

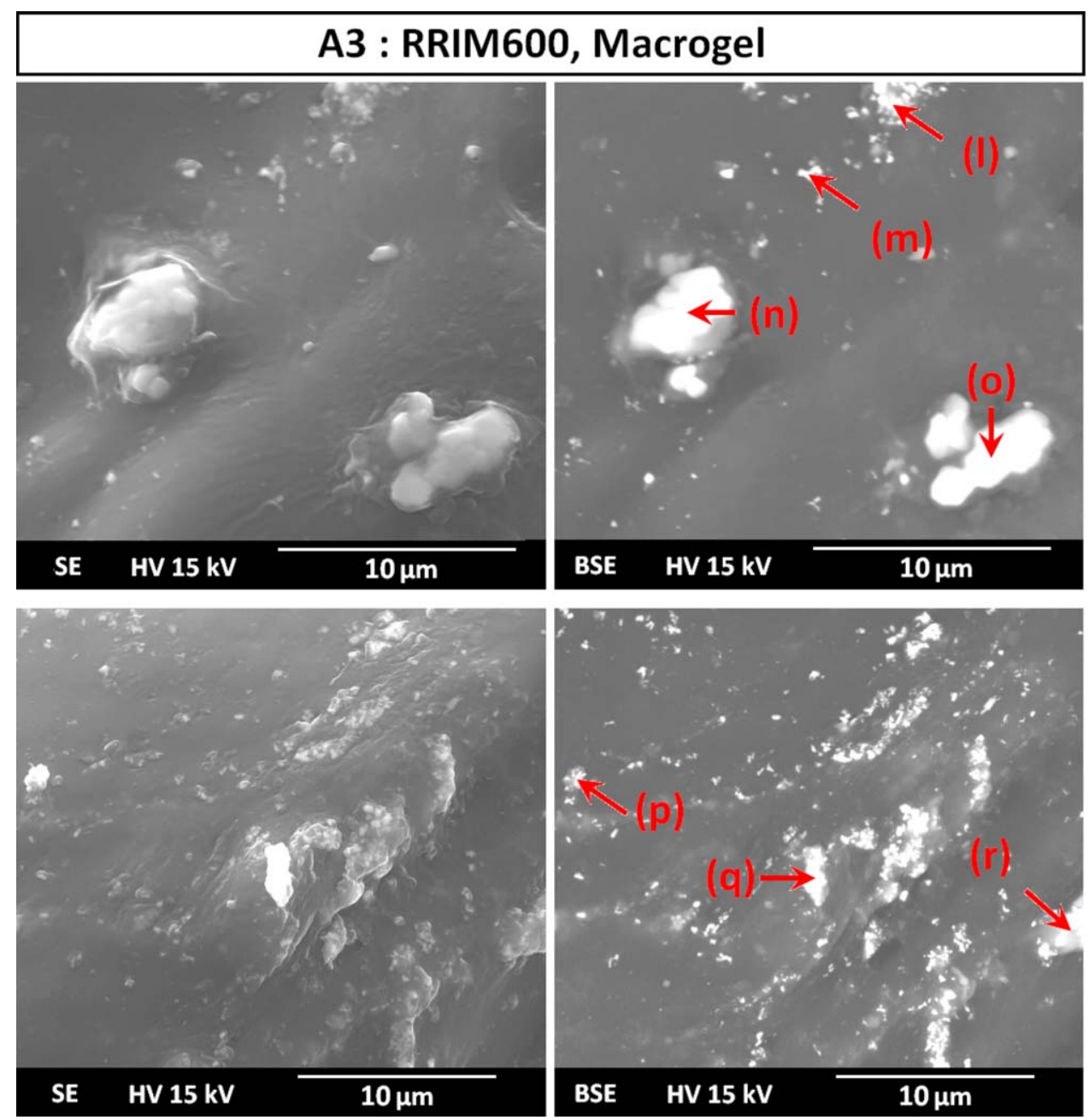

Figure 7. SEM observations (SE (right) and BSE (left) modes) of the surface of the RRIM600 macrogel (A3). EDX microanalyses were performed to determine the composition of the areas (l) to (r) (See Table VII). [Color figure can be viewed in the online issue, which is available at wileyonlinelibrary.com.]

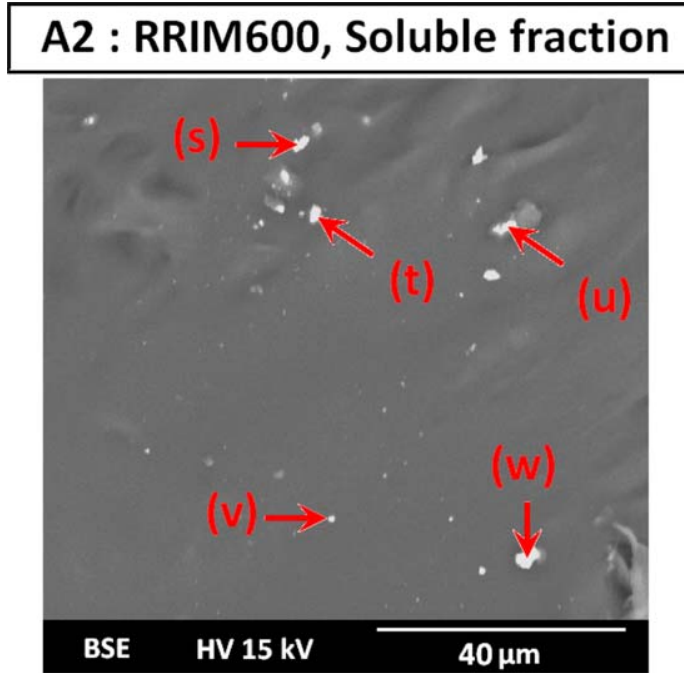

Figure 8. SEM observation (BSE mode) of the surface of the RRIM600 soluble fraction (A2). EDX microanalyses were performed to determine the composition of the areas (s) to (w) (See Table VII). [Color figure can be viewed in the online issue, which is available at wileyonlinelibrary.com.] compounds, which have yet to be found in Hevea brasiliensis latex, might reflect some possible pollution occurring during the collection and processing of NR. For example, sand could have been added somehow during latex coagulation and maturation in the tapping cup. Some minerals might also have been present in the water used in the coagula washing steps.

\section{CONCLUSIONS}

Two natural rubber (NR) samples of TSR10 grade, made from the latex of clones RRIM600 and GT1, and their corresponding soluble fraction and macrogel were first characterized using ICP-MS. The concentrations of the main mineral compounds were measured. The macrogels of both samples were found to be the most concentrated in minerals. The mineral concentrations were very low in the soluble fractions, indicating that minerals are concentrated in the macrogel of NR during extraction. SEM/EDX analyses of rubber sheets made from the different fractions showed that some minerals are present in micronsized aggregates. The composition of those mineral aggregates was found to be highly variable, and also suggested possible pollution of coagula during the processing of the NR samples. 
On the other hand, the inhomogeneous distribution of mineral aggregates in the macrogel seems to indicate that these mineral aggregates do not have a major influence over the structure of macrogel. Moreover, a large quantity of aggregates can be eliminated with ultrapure water.

\section{ACKNOWLEDGMENTS}

The authors would like to thank the members of the CANAOPT project: Hutchinson, Anvis, Emac, Metaldyne, Michelin, the LRCCP and the Université du Maine. Thanks to our local partners: S.A.P.H. (Côte d'Ivoire) and Thai Hua (Thailand). We are also grateful to the French BPI (Banque Publique d'Investissement), to the French regions and departments of Bourgogne (CR), Pays de la Loire (CR), Languedoc-Roussillon (FEDER), Loiret (CG45), Nièvre (CG58) and Pyrénées-Atlantiques (CG64), and to the Montargis agglomeration for financial support. ICP-MS analyses were carried out on the LipPol-Green platform. We kindly thank Agropolis Fondation for the financial support of the platform (Grant 0801-006).

\section{REFERENCES}

1. Eng, A. H.; Tanaka, Y. Trends Polym. Sci. 1993, 3, 493.

2. Vaysse, L.; Bonfils, F.; Sainte-Beuve, J.; Cartault, M. In Polymer Science: A Comprehensive Reference. Polymers for a Sustainable Environment and Green Energy; McGrath, J. E.; Hickner, M. A.; Höfer, R., Eds.; Elsevier: Amsterdam, 2012, Chapter 10.1.7, p 281.

3. Liengprayoon, S.; Chaiyut, J.; Sriroth, K.; Bonfils, F.; SainteBeuve, J.; Dubreucq, E.; Vaysse, L. Eur. J. Lipid Sci. Technol. 2013, 115, 1021.

4. Kosugi, K.; Kawahara, S. Colloid Polym. Sci. 2015, 293, 135.

5. Nimpaiboon, A.; Sakdapipanich, J. Polym. Test. 2013, 32, 1408.

6. McMahan, C.; Kostyal, D.; Lhamo, D.; Cornish, K. J. Appl. Polym. Sci. 2015, 132, DOI: 10.1002/app.42051.

7. Amnuaypornsri, S.; Sakdapipanich, J.; Tanaka, Y. J. Appl. Polym. Sci. 2009, 111, 2127.

8. Hasma, H.; Othman, A. B. J. Nat. Rubber Res. 1990, 5, 1.

9. Wang, P. Y.; Wang, Y. Z.; Zhang, B. L.; Huang, H. H. J. Appl. Polym. Sci. 2012, 126, 1183.

10. Tanaka, Y.; Tarachiwin, L. Rubber Chem. Technol. 2009, 82, 283.

11. Allen, P. W.; Bristow, G. M. J. Appl. Polym. Sci. 1993, 7, 603.

12. Campbell, D. S.; Fuller, K. N. G. Rubber Chem. Technol. 1984, 57, 104.

13. Subramaniam, A. Proceedings of the International Rubber Technology Conference, Kuala Lumpur, Malaysia, 1993.
14. Voznyakovskii, A. P.; Dmitrieva, I. P.; Klyubin, V. V.; Tumanova, S. A. Polym. Sci. A: Chem. Phys. 1996, 38, 1153.

15. Tarachiwin, L.; Sakdapipanich, J. T.; Tanaka, Y. Rubber Chem. Technol. 2003, 76, 1185.

16. Rippel, M. M.; Leite, C. A. P.; Lee, L. T.; Galemberg, F. Colloid Polym. Sci. 2005, 283, 570.

17. Rippel, M. M.; Leite, C. A. P.; Galembeck, F. Anal. Chem. 2002, 74, 2541.

18. Rolere, S.; Liengprayoon, S.; Vaysse, L.; Sainte-Beuve, J.; Bonfils, F. Polym. Test. 2015, 43, 83.

19. Sekhar, B. C. Proceedings of the 4th Rubber Technology Conference, London, 460, 1962.

20. Shiibashi, T. Nippon Comu Kyokaishi, 60(6), 298; translated (1987) in Int. Polym. Sci. Technol. 1987, 14, T/33.

21. Gan, S. N.; Ting, K. F. Polymer 1993, 34, 2142.

22. Yip, E.; Chin, H. C. J. Rubber Res. Inst. Malaysia 1997, 25, 31.

23. Jacob, J. L.; d'Auzac, J.; Prevôt, J. C. Clin. Rev. Allergy 1993, $11,325$.

24. Gopalakrishnan, J.; Thomas, M.; Philip, A.; Krishnakumar, R.; Jacob, J. Nat. Rubber Res. 2010, 23, 93.

25. Belmas, R. Rubber Chem. Technol. 1952, 25, 124.

26. Flint, C. F.; Ramage, H. J Soc. Chem. Ind. 1935, 54, 337.

27. Traoré, M. S.; Diarrassouba, M.; Okoma, K. M.; Dick, K. E.; Soumahin, E. F.; Coulibaly, L. F.; Obouayeba, S. Agric. Biol. J. N. Am. 2011, 2, 1251.

28. Silpi, U.; Chantuma, P.; Kasemsap, P.; Thaler, P.; Thanisawanyangkura, S.; Lacointe, A.; Ameglio, T.; Gohet, E. Proceedings of the RRDB annual Meeting, Kunming, China, 2004.

29. George, U. U.; Andy, J. A.; Joseph, A. Int. J. Sci. Technol. Res. 2014, 3, 377.

30. Rubber Statistical Bulletin, April - June 2015 edition.

31. Bandura, D. R.; Baranov, V. I.; Tanner, S. D. Anal. Chem. 2002, 74, 1497.

32. Tangpakdee, J.; Tanaka, Y. Rubber Chem. Technol. 1997, 70, 707.

33. Lu, F. J.; Hsu, S. L. Rubber Chem. Technol. 1987, 60, 647.

34. Goldstein, J.; Newbury, D. E.; Joy, D. C.; Lyman, C. E.; Echlin, P.; Lifshin, E.; Sawyer, L.; Michael, J. R. Scanning Electron Microscopy and X-ray Microanalysis: 3rd ed.; Springer Publishers: New York, 2003.

35. Wisunthorn, S.; Liengprayoon, S.; Vaysse, L.; Beuve, J. S.; Bonfils, F. J. Appl. Polym. Sci. 2012, 124, 1570.

36. Bonfils, F.; Doumbia, A.; Char, C.; Sainte-Beuve, J. J. Appl. Polym. Sci. 2004, 97, 903. 